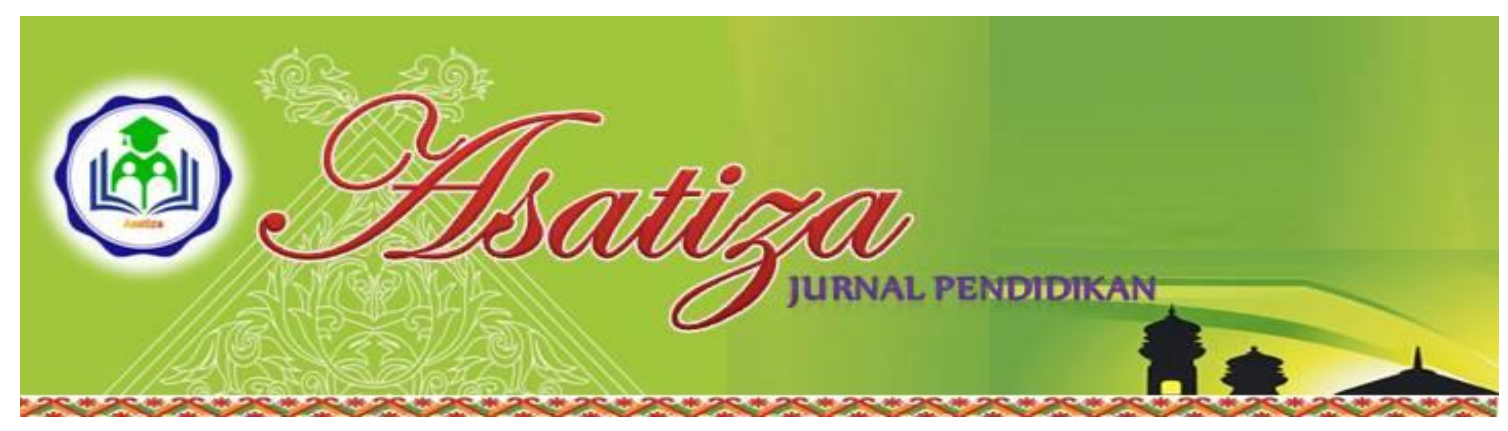

\title{
KINERJA GURU PENDIDIKAN AGAMA ISLAM DALAM MENGIMPLEMENTASI RENCANA PELAKSANAAN PEMBELAJARAN \\ PADA PROSES PEMBELAJARAN PENDIDIKAN AGAMA ISLAM DI SEKOLAH MENENGAH PERTAMA MUHAMMADIYAH TEMBILAHAN
}

\author{
Rahman Sudaisih Syamrabusta ${ }^{1}$ \\ ${ }^{1}$ STAI Auliaurrasyidin Tembilahan
}

\section{Abstrak}

Tujuan penelitian adalah untuk mengetahui kinerja guru Pendidikan Agama Islam dalam mengimplementasi Rencana Pelaksanaan Pembelajaran (RPP) pada proses pembelajaran Pendidikan Agama Islam di Sekolah Menengah Pertama Muhammadiyah Tembilahan.

Subjek dalam penelitian adalah guru Pendidikan Agama Islam di Sekolah Menengah Pertama Muhammadiyah Tembilahan. Sedangkan objek penelitian adalah kinerja guru Pendidikan Agama Islam dalam mengimplementasi Rencana Pelaksanaan Pembelajaran (RPP) pada proses pembelajaran Pendidikan Agama Islam di Sekolah Menengah Pertama Muhammadiyah Tembilahan. Populasi dalam penelitian ini adalah guru Pendidikan Agama Islam yang berjumlah 2 guru. Sampel diambil dari seluruh populasi yang ada. Teknik pengumpulan data yang penulis gunakan adalah observasi dan dokumentasi. Teknik analisa data yang digunakan dalam penelitian ini adalah analisis data dengan menggunakan rumus persentase.

Berdasarkan hasil penelitian dapat disimpulkan bahwa Kinerja guru Pendidikan Agama Islam dalam mengimplementasi Rencana Pelaksanaan Pembelajaran (RPP) pada proses pembelajaran Pendidikan Agama Islam di Sekolah Menengah Pertama Muhammadiyah Tembilahan" nilai persentasenya adalah $74 \%$, dan tergolong "Baik" karena terletak pada interval 61\%-80\%.

Kata Kunci: Kinerja Guru, Rencana Pelaksanaan Pembelajaran (RPP), Pendidikan Agama Islam

\section{A. PENDAHULUAN}

\section{Latar belakang}

Pendidikan Agama Islam merujuk kongres sedunia mengenai tujuan pendidikan Islam adalah kedudukan Islam harus mencapai pertumbuhan kepribadian manusia yang menyeluruh secara seimbang melalui latihan jiwa, intelek diri manusia yang rasional, perasaan dan indra. ${ }^{1}$

Peningkatan pendidikan sebagai bagian yang tidak terpisahkan dari proses pengembangan sumber daya manusia, harus dilakukan secara terencana, terarah, dan intensif, sehingga mempu menyiapkan bangsa Indonesia memasuki

${ }^{1}$ Faisol, Pendidikan Islam Perspektif, (Jakarta: Gue Pedia Com, 2015), hlm.11. 
era globalisasi yang sarat dengan persaingan. ${ }^{2}$

Guna meningkatkan Pendidikan Agam Islam, sangat diperlukan campur tangan guru yang kompeten dalam bidangnya. Guru merupakan komponen penting dalam dunia pendidikan, oleh karenanya perhatian yang lebih perlu diberikan agar dapat menciptakan guru yang berkualitas sehingga hal tersebut dapat menunjang proses pembelajaran. Guru memiliki peranan yang sangat penting dalam menentukan kualitas dan kualitas pengajaran yang dilaksanakannya.

Tugas ini merupakan tanggung jawab guru sebagai bentuk kompetensi yang dimiliki oleh setiap guru. Namun dalam kenyataan yang ada dibeberapa sekolah masih banyak guru membuat Rencana Pelaksanaan Pembelajaran (RPP) masih tidak sesuai dengan keadaan lingkungan sekolah, bahkan masih banyak guru yang hanya mengopi Rencana Pelaksanaan Pembelajaran (RPP) dari sekolah lain.

Dengan penginglementasian Rencana Pelaksanaan Pembelajaran (RPP) yang baik mampu memotivasi serta memberdayakan guru agar tercipta kinerja yang baik serta mampu berperan sebagai guru yang profesional disamping guru itu sendiri yang mampu meningkatkan kinerja guru.

Perencanaan pengajaran merupakan hal yang sangat penting dalam konteks proses belajar mengajar. Pengajaran

${ }^{2}$ Depdiknas, Manajemen Peningkatan Mutu Berbasis Sekolah, (Jakarta: Dir PMU, 2000), hlm. 47

3 Werkanis dan Marlius Hamadi, Strategi Mengajar, dalam pelaksanaan Kurikulum merupakan dasar bagi peserta didik dalam menerima pengalaman belajar di kelas. Keberhasilan anak didik dalam belajar banyak ditentukan oleh baik buruknya suatu perencanaan pengajaran yang disusun oleh guru. ${ }^{3}$

Implementasi Rencana Pelaksanaan Pembelajaran (RPP) harus ditunjang oleh kinerja guru yang ditunjukan dengan performa mengajar di kelas. Pelaksanaan proses belajar mengajar di kelas merupakan tugas pokok guru yang harus dilaksanakan secara efektif.

Kinerja guru merupakan hasil kerja seorang guru dalam melaksanakan tugasnya dalam proses pembelajaran sesuai dengan bidang dan keahlian yang dimilikinya. ${ }^{4}$ Penyelenggaraan lembagalembaga pendidikan di negara manapun di dunia dipandang sebagai suatu program yang bernilai strategis. Hal ini berdasarkan satu asumsi bahwa proses pendidikan merupakan sebuah proses yang dengan sengaja dilaksanakan semata-semata bertujuan untuk mencerdaskan bangsa. Melalui proses pendidikan akan terbentuk sosok-sosok individu sebagai sumber daya manusia yang akan berperan besar dalam proses pembangunan bangsa dan negara. Hal ini dapat dimengerti karena kinerja guru itu berhubungan dengan pencapaian semua tujuan yang ditetapkan melalui perencanaan pembelajaran.

Proses pembelajaran pada mata pelajaran Pendidikan Agama Islam akan tercapai apabila proses belajar mengajar

Berbasis Kompetensi, (Pekanbaru: Sutra Benta Perkasa, 2005), hlm. 9

${ }^{4}$ Muhammad Ali, Pelaksanaan Proses Belajar Mengajar yang Bermutu, (Semarang: Intiusi Press, 2009), hlm. 133. 
yang diselenggarakan di kelas benarbenar efektif dan berguna untuk mencapai kemampuan pengetahuan, sikap dan keterampilan yang diharapkan. Keberadaan guru dalam proses kegiatan belajar mengajar sangat berpengaruh, maka sudah semestinya kinerja mengajar guru harus diperhatikan.

Menurut Ma'as Shobirin berdasarkan Permendikbud Nomor 65 Tahun 2013 Tentang standar proses, Rencana Pelaksanaan Pembelajaran (RPP) adalah rencana kegiatan pembelajaran tatap muka untuk satu pertemuan atau lebih. RPP dikembangkan dari silabus yang sudah ada untuk mengarahkan kegiatan pembelajaran peserta didik dalam upaya untuk mencapai kompetensi dasar. ${ }^{5}$

Lingkup Rencana Pembelajaran paling luas mencakup 1 (satu) kompetensi dasar yang terdiri atas 1 (satu) atau beberapa indikator untuk 1 (satu) kali pertemuan atau lebih.6 Implementasi kinerja guru dalam menggunakan Rencana Pelaksanaan Pembelajaran (RPP) harus dimiliki oleh semua guru yang bertugas mengajar di kelas.

Berdasarkan hasil pengamatan awal yang penulis lakukan di Sekolah Menengah Pertama Muhammadiyah Tembilahan kinerja mengajar dapat dilihat dari cara mengajar guru namun dalam pelaksanaannya penulis melihat beberapa gelaja-gejala sebagai berikut;

5 Ma'as Shobirin, Konsep dan Implementasi Kurikulum 2013 di Skeolah Dasar, (Yogyakarta: Deepublish, 2013), hlm. 183

${ }^{6}$ Ahmadi, Guru dan Langkah-langkah Pembelajaran, (Jakarta: Atlanta Press, 2009), h. 21.

${ }^{7}$ Pengamatan awal Penelitian
Guru kurang memperhatikan Rencana Pelaksanaan Pembelajaran (RPP) saat mengajar. Guru kurang menyusun kriteria penilaian dalam membuat Rencanan Pelaksanaan Pembelajaran tidak sesuai dengan langkah-langkah Rencana Pelaksanaan Pembelajaran (RPP). Guru jarang menyebutkan tujuan pembelajaran yang terdapat dalam Rencana Pelaksanaan Pembelajaran (RPP) ketika mengajar. Guru kurang memberikan motivasi akan pentingnya kompetensi yang akan dipelajari. Guru jarang menggunakan metode yang bervariasi sesuai dengan Rencana Pelaksanaan Pembelajaran (RPP) ketika mengajar.7

\section{Pengertian Kinerja Guru}

Adapun tentang kinerja mengajar adalah perilaku atau respons yang memberi hasil yang mengacu kepada apa yang mereka kerjakan ketika dia menghadapi suatu tugas. Kinerja pengajar menyangkut semua kegiatan atau tingkah laku yang dialami tenaga pengajar. $^{8}$

Kinerja menurut Anwar Prabu Mangkunegara, "Kinerja" (Prestasi Kerja) adalah hasil kerja secara kualitas dan kuantitas yang dicapai oleh seseorang pegawai dalam melaksanakan tugasnya sesuai dengan tanggung jawab yang diberikan kepadanya. ${ }^{9}$ Melayu Hasibuan mengemukakan "kinerja" (Prestasi Kerja) adalah suatu hasil kerja seseorang

${ }^{8}$ Sofan Amri dan Lif Khairu Ahmadi, Kontruksi Pengembangan Pembelajaran, (Bandung: Alfabeta, 2010), hlm. 87.

${ }^{9}$ Anwar Prabu Mangkunegara, Manajemen SDM Perusahaan, (Bandung: PT. Remaja Rosdakarya, 2000), hlm. 67. 
dalam melaksanakan tugas-tugas yang dibebankan kepadanya yang didasarkan atas kecakapan pengalaman dan kesanggupan serta ketepatan waktu dalam menyelesaikan tugasnya. ${ }^{10}$

Berdasarkan pendapat-pendapat di atas, dapat penulis simpulkan bahwa implementasi kinerja guru merupakan suatu pelaksanaan hasil kerja seorang guru dalam melaksanakan tugas-tugas yang dibebankan kepadanya yang didasarkan atas kecakapan pengalaman dan kesanggupan serta ketepatan waktu dalam menyelesaikan tugasnya

Dalam dunia pendidikan, kinerja guru dapat dilihat dari berbagai tugas yang telah diamanahkan dalam undangundang. Pada hakikatnya, kinerja guru bukan hanya sebatas melaksanakan kurikulum sebagai beban kerja, justru banyak tugas lain yang harus dilaksanakan dan itu terwujud dalam bentuk kinerja seorang guru. Inilah hakikatnya tuntutan profesionalitas yang telah disematkan kepada beban dan tanggung jawab kepada mereka. ${ }^{11}$

Menurut Kusmianto standar kinerja guru itu berhubungan dengan kualitas guru dalam menjalankan tugasnya seperti; bekerja dengan siswa secara individu, persiapan dan perencanaan pembelajaran, pendayagunaan media pembelajaran, melibatkan siswa dalam

${ }^{10}$ Melayu Hasibuan, Manajemen Sumber Daya Manusia, (Yogyakarta: Sinar Grafika Offset, 2002), hlm. 34.

${ }^{11}$ E. Mulyasa, Menjadi Guru Profesional; Menciptakan pembelajaran kreatif dan menyenangkan, (Jakarta: Rosdakarya, 2008), hlm, 35-65.

${ }^{12}$ Rosman, Belajar dan Pembelajaran Berbasis Komputer, Mengembangkan Profesionalisme Guru Abad 21, (Bandung: Afabeta, 2012), hlm. 32 berbagai pengalaman belajar dan kepemimpinan yang aktif dari guru. ${ }^{12}$

Pendapat lain diutarakan Suparlan menyatakan ada empat tugas gugusan kemampuan yang harus dikuasai oleh seorang guru. Kemampuan yang harus dikuasai oleh seorang guru, yaitu; merencanakan program belajar mengajar, melaksanakan dan mepimpin proses belajar mengajar, menialia kemajuan proses belajar mengajar dan membina hubungan dengan peserta didik. ${ }^{13}$

Pada hakekatnya kinerja guru adalah prilaku yang dihasilkan seorang guru dalam meaksanakan tugasnya sebagai $\mathrm{p}$ endidik dan pengajar ketika mengajar di depan kelas, sesuai dengan criteria tertentu. Kinerja seorang guru akan nampak pada situasi dan kondisi kerja sehari-hari, kinerja dapat dilihat dalam aspek kegiatan dalam melaksanakn kegiatan atau tugas tersebut.

\section{Implementasi \\ Pelaksanaan Pembelajaran}

Implementasi atau pelaksanaan adalah inisiatif dari rencana tindakan untuk mencapai tujuan yang spesifik. ${ }^{14}$

Implementasi adalah proses untuk memastikan terlaksananya suatu kebijakan dan tercapainya kebijakan tersebut. $^{15}$

13 Suparlan, Tanya Jawab Pengembangan Kurikulum dan Materi Pembelajaran, (Jakarta: Bumi Aksara, 2011), hlm. 51.

${ }^{14}$ Ferry Efendi dan Makhfudli, Keperawatan Kesehatan Komunitas, (Jakarta: Salemba Medika, 2009), hlm. 157

${ }^{15}$ Saudah Racman, Implementasi Kebijakan Perusahaan, (Bandung: Econom.Ce, 2007), hlm. 39. 
Berdasarkan beberapa pendapat diatas, maka dapat disimpulkan bahwa implementasi adalah pelaksanaan atau penerapan suatu rencana yang telah dipersiapkan sebelumnya.

Rencana Pelaksanaan Pembelajaran (RPP) adalah rencana yang menggambarkan prosedur dan pengorganisasian pembelajaran untuk mencapai suatukompetensi dasar yang ditetapkan dalam Standar Isi dan dijabarkan dalam silabus. ${ }^{16}$

Dalam kurikulum tingkat satuan pendidikan RPP merupakan komponen yang penting. Dalam hal ini guru merupakan salah satu yang memegang peranan paling penting dalam merancang suatu RPP oleh karena itu dituntut adanya suatu sikap profesional dari seorang guru. Kemampuan membuat rencana pelaksanaan pembelajaran merupakan hal yang harus dimiliki oleh seorang guru yang merupakan bagian dari kompetensi guru.

Langkah-langkah minimal dari menggunakan Rencana Pelaksanaan Pembelajaran (RPP), dimulai dari mengidentifikasi tujuan secara umum pembelajaran hingga mengembangkan strategi pembelajaran. Setiap komponen mempunyai arah pengembangan masingmasing, namun semua merupakan suatu kesatuan. Kinerja mengajar guru menggunakan Rencana Pelaksanaan Pembelajaran (RPP) dapat dilihat dari kegiatan mengajar guru, yaitu:

\section{a. Pendahuluan}

Pendahuluan merupakan kegiatan awal dalam suatu pertemuan pembelajaran yang ditujukan untuk

${ }^{16}$ Kunandar, Guru Profesional, Impelemtasi Kurikulum Tingkat Satuan Pendidikan (KTSP) membangkitkan motivasi dan memfokuskan perhatian peserta didik untuk berpartisipasi aktif dalam proses pembelajaran. Dalam kegiatan pendahuluan, guru:

1) Menyiapkan peserta didik secara psikis dan fisik untuk mengikuti proses pembelajaran

2) Mengajukan pertanyaanpertanyaan yang mengaitkan pengetahuan sebelumnya dengan materi yang akan dipelajari

3) Menjelaskan tujuan pembelajaran atau kompetensi dasar yang akan dicapai

4) Menyampaikan cakupan materi dan penjelasan uraian kegiatan sesuai silabus.

\section{b. Kegiatan Inti}

Kegiatan inti merupakan proses pembelajaran untuk mencapai KD. Kegiatan pembelajaran dilakukan secara interaktif, inspriratif, menyenangkan, menantang, memotivasi peserta didik untuk berpartisipasi aktif, serta memberikan ruang yang cukup bagi prakarya, kreativitas dan kemandirin sesuai dengan bakat, minat dan perkembangan fisik serta psikologis peserta didik. Kegiatan inti dilakukan secara sistematis melalui proses eksplorasi, elaborasi dan konfirmasi.

Dalam kegiatan eksplorasi guru;

1) Melibatkan peserta didik mencari informasi yang luas dan dalam tentang topik/tema materi yang akan dipelajari dengan menerapkan

dan Sukses dalam sertifikasi Guru, (Jakarta: Rajawali Pers, 2014), hlm. 263. 
prinsip alam tekambang jadi guru dan belajar dari aneka sumber

2) Menggunakan beragam pendekatan pembelajaran, media pembelajaran dan sumber belajar

3) Memfasilitasi terjadinya interaksi antar peserta didik serta antara peserta didik dengan guru, lingkungan dan sumber belajar lainnya.

4) Melibatkan peserta didik secara aktif dalam setiap kegiatan pembelajaran

5) Memfasilitasi peserta didik melakukan percobaan dilapangan.

Dalam kegiatan elaborasi, guru:

1) Membiasakan peserta didik membaca dan menulis yang beragam melalui tugas-tugas tertentu yang bermakna

2) Memfasilitasi peserta didik melalui beragam tugas, diskusi danlainnya untuk memunculkan gagasan baru baik secara lisan maupun tertulis.

3) Memberikan kesempatan untuk berpikir, menganalisis, menyelesaikan masalah dan bertindak tanpa rasa takut.

4) Memfasilitasi peserta didik dalam pembelajaran kooperatif dan kolaboratif.

5) Memfasilitasi peserta didik berkompetisi secara sehat untuk meningkatkan prestasi belajar

6) Memfasilitasi peserta didik membuat laporan eskplorasi yang dilakukan baik lisan maupun tertulis

7) Memfasilitasi peserta didik untuk menyajikan hasil kerja individu maupun kelompok
8) Memfasilitasi peserta didik melakukan pameran, turnamen, festifal, serta produk yang dihasilkan

9) Memfasilitasi peserta didik melakukan kegiatan yang menumbuhkan kebanggaan dan rasa percaya diri peserta didik.

Dalam kegiatan konfirmasi, guru:

1) Memberikan umpan balik positif dan penguatan dalam bentuk lisan, tulisan, isyarat, maupun hadiah terhadap keberhasilan peserta didik.

2) Meberikan konfirmasi terhadap hasil eksplorasi elaborasi peserta didik melalui berbagai sumber

3) Memfasilitasi peserta didik melakukan refleksi untuk memperoleh pengalaman belajar yang telah dilakukan

4) Memfasilitasi peserta didik untuk memperoleh pengalaman yang bermakna dalam mencapai kompetensi dasar.

\section{c. Kegiatan Penutup}

Dalam kegiatan penutup, guru:

1) Bersama-sama dengan peserta didik membuat rangkuman pelajaran

2) Melakukan penilaian

3) Memberikan umpan balik

4) Merencanakan kegiatan tindak lanjut dalam bentuk pembelajaran remedial kepada peserta didik 
5) Menyampaikan rencana pembelajaran pada pertemuan berikutnya. ${ }^{17}$

Adapun implementasi langkahlangkah Rencana Pelaksanaan Pembelajaran (RPP) di Sekolah Menengah Pertama Muhammadiyah Tembilahan yaitu:

\section{a. Kegiatan Pendahuluan}

Dalam kegiatan pendahuluan:

1) Guru melakukan pembukaan dengan salam pembuka dan berdoa untuk memulai pembelajaran.

2) Guru memeriksa kehadiran siswa

3) Guru menyiapkan fisik dan psikis siswa dalam mengawali kegiatan pembelajaran

4) Guru melakukan apersepsi dengan cara; mengaitkan materi pembelajaran yang akan dilakukan dengan pengalaman materi sebelumnya, mengingatkan kembali materi prasyarat dengan bertanya, mengajukan pertanyaan yang ada kaitannya dengan pembelajaran yang akan dilakukan.

5) Guru memberikan motivasi kepada siswa dengan menyampaikan tujuan pembelajaran

6) Guru menjelaskan mekanisme pelaksanaan pengalaman belajar sesuai dengan langkah-langkah pembelajaran.

\section{b. Kegiatan Inti}

Dalam kegiatan ini;

1) Guru memfokuskan pada topik materi pelajaran

2) Guru memberikan kesempatan kepada siswa untuk mengidentifikasi sebanyak mungkin pertanyaan yang berkaitan dengan materi yang disajikan

3) Guru memberikan kesempatan kepada siswa untuk berdikusi mengolah data hasil pengamatan belajar siswa.

4) Guru memberikan kesempatan kepada siswa untuk menyimpulkan hasil belajar

5) Guru meminta siswa menyelesaikan uji kompetensi yang terdapat pada buku pegangan siswa untuk menecek penguasaan siswa

\section{c. Kegiatan Penutup}

Dalam kegiatan penutup:

a. Guru meminta siswa membuat resume dengan bimbingan guru tentang poin-poin penting dalam belajar

b. Guru memberikan pekerjaan rumah kepada siswa

c. Guru memeriksa pekerjaan siswa

d. Guru memberikan penghargaan dengan member kan nilai pada lembar kerja siswa. ${ }^{18}$

\footnotetext{
${ }^{17}$ Kunandar, Op.cit., hlm. 267-269
}

${ }^{18}$ Rencana Pelaksanaan Pembelajaran (RPP) di Sekolah Menengah Pertama Muhammadiyah Tembilahan 


\section{B. METODOLOGI}

Subjek dalam penelitian ini adalah Guru Pendidikan Agama Islam kelas VII di Sekolah Menengah Pertama Muhammadiyah Tembilahan. Sementara objek dalam penelitian ini adalah kinerja guru Pendidikan Agama Islam dalam mengimplementasikan Rencana Pelaksanaan Pembelajaran (RPP) di Sekolah Menengah Pertama Muhammadiyah Tembilahan. Adapun populasi dalam penelitian ini adalah seluruh guru Pendidikan Agama Islam di Sekolah Menengah Pertama Muhammadiyah Tembilahan yang berjumlah 2 orang guru. Adapun metode penilitan yang dilakukan penulis dalam penelitian tersebut adalah: observasi dan dokumentasi. Jenis penelitian ini disebut penelitian deskriptif kualitatif.

\section{PEMBAHASAN}

Setelah diperhatikan penyajian data melalui observasi, selanjutnya data tersebut dibahas sebagai berikut:

\section{Rekapitulasi Data Hasil Penelitian}

Kinerja guru Pendidikan Agama Islam dalam mengimplementasi Rencana Pelaksanaan

Pembelajaran (RPP) pada proses pembelajaran Pendidikan Agama Islam di Sekolah Menengah Pertama Muhammadiyah Tembilahan

\begin{tabular}{|c|c|c|c|c|c|}
\hline & \multirow{3}{*}{$\begin{array}{c}\text { Item Indikator } \\
\text { Observasi }\end{array}$} & \multicolumn{4}{|c|}{$\begin{array}{c}\text { Alternatif } \\
\text { Jawaban }\end{array}$} \\
\hline & & \multicolumn{2}{|c|}{ Ya } & \multicolumn{2}{|c|}{ Tidak } \\
\hline & & $\mathbf{F}$ & $(\%)$ & $\mathbf{F}$ & $(\%)$ \\
\hline 1 & \multicolumn{5}{|l|}{ Kegiatan pendahuluan } \\
\hline $\mathrm{a}$ & $\begin{array}{l}\text { Apakah guru } \\
\text { melakukan } \\
\text { pembukaan dengan } \\
\text { salam pembuka? }\end{array}$ & 10 & 83,3 & 2 & 16,7 \\
\hline $\mathrm{b}$ & $\begin{array}{lr}\text { Apakah } & \text { guru } \\
\text { mengajak } & \text { siswa } \\
\text { berdoa } & \text { untuk }\end{array}$ & 7 & 58,3 & 5 & 41,7 \\
\hline
\end{tabular}

\begin{tabular}{|c|c|c|c|c|c|}
\hline & $\begin{array}{l}\text { memulai } \\
\text { pembelajaran? }\end{array}$ & & & & \\
\hline $\mathrm{c}$ & $\begin{array}{lr}\text { Apakah } & \text { guru } \\
\text { memeriksa } & \\
\text { kehadiran siswa } \\
\text { dengan melakukan } \\
\text { absensi? }\end{array}$ & 10 & 83,3 & 2 & 16,7 \\
\hline $\mathrm{d}$ & $\begin{array}{lr}\text { Apakah } & \text { guru } \\
\text { mengaitkan materi } \\
\text { pembelajaran yang } \\
\text { akan dilakukan } \\
\text { dengan pengalaman } \\
\text { materi sebelumnya } \\
\text { yang telah } \\
\text { disampaikan? }\end{array}$ & 8 & 66,7 & 4 & 33,3 \\
\hline $\mathrm{e}$ & $\begin{array}{lr}\text { Apakah guru } \\
\text { bertanya tentang } \\
\text { materi yang sudah } \\
\text { di pelajari? }\end{array}$ & 7 & 58,3 & 5 & 41,7 \\
\hline $\mathrm{f}$ & $\begin{array}{l}\text { Apakah guru } \\
\text { mengajukan } \\
\text { pertanyaan yang ada } \\
\text { kaitannya dengan } \\
\text { pembelajaran yang } \\
\text { akan dipelajari? }\end{array}$ & 9 & 75 & 3 & 25 \\
\hline $\mathrm{g}$ & $\begin{array}{l}\text { Apakah guru } \\
\text { memberikan } \\
\text { motivasi kepada } \\
\text { siswa dengan } \\
\text { menyampaikan } \\
\text { tujuan } \\
\text { pembelajaran? }\end{array}$ & 8 & 66,7 & 4 & 33,3 \\
\hline 2 & \multicolumn{5}{|c|}{ Kegiatan inti } \\
\hline $\mathrm{a}$ & $\begin{array}{l}\text { Apakah guru } \\
\text { memfokuskan } \\
\text { dengan mencatat } \\
\text { topik } \quad \text { materi } \\
\text { pelajaran di papan } \\
\text { tulis? }\end{array}$ & 11 & 91,7 & 1 & 8,3 \\
\hline $\mathrm{b}$ & \begin{tabular}{lr} 
Apakah & guru \\
memberikan & \\
kesempatan & kepada \\
siswa & untuk \\
mengajukan & \\
\multicolumn{2}{l}{ sebanyak mungkin } \\
pertanyaan & yang \\
berkaitan & dengan \\
materi & yang \\
disajikan? &
\end{tabular} & 8 & 66,7 & 4 & 33,3 \\
\hline $\mathrm{c}$ & $\begin{array}{lr}\text { Apakah } & \text { guru } \\
\text { memberikan } & \\
\text { kesempatan } & \text { kepada } \\
\text { siswa } & \text { untuk } \\
\text { berdikusi } & \text { mengolah } \\
\text { data } & \text { hasil } \\
\text { pengamatan } & \text { belajar } \\
\text { siswa? } & \\
\end{array}$ & 8 & 66,7 & 4 & 33,3 \\
\hline
\end{tabular}




\begin{tabular}{|c|c|c|c|c|c|}
\hline $\mathrm{d}$ & $\begin{array}{l}\text { Apakah guru } \\
\text { memberikan } \\
\text { kesempatan kepada } \\
\text { siswa untuk } \\
\text { menyimpulkan hasil } \\
\text { belajar? }\end{array}$ & 8 & 66,7 & 4 & 33,3 \\
\hline $\mathrm{e}$ & $\begin{array}{l}\text { Apakah guru } \\
\text { meminta siswa } \\
\text { menyelesaikan } \\
\text { latihan belajar? }\end{array}$ & 9 & 75 & 3 & 25 \\
\hline 3 & \multicolumn{5}{|l|}{ Kegiatan penutup } \\
\hline $\mathrm{a}$ & $\begin{array}{lr}\text { Apakah } & \text { guru } \\
\text { meminta } & \text { siswa } \\
\text { membuat } & \text { resume } \\
\text { tentang } & \text { poin-poin } \\
\text { penting } & \text { dalam } \\
\text { belajar? } & \\
\end{array}$ & 11 & 91,7 & 1 & 8,3 \\
\hline $\mathrm{b}$ & $\begin{array}{l}\text { Apakah guru } \\
\text { memberikan } \\
\text { pekerjaan rumah } \\
(\mathrm{PR}) \quad \text { kepada } \\
\text { siswa? }\end{array}$ & 8 & 66,7 & 4 & 33,3 \\
\hline $\mathrm{c}$ & $\begin{array}{lr}\text { Apakah } & \text { guru } \\
\text { memeriksa } & \\
\text { pekerjaan } & \text { siswa } \\
\text { hasil } & \text { latihan } \\
\text { siswa? } & \\
\end{array}$ & 9 & 75 & 3 & 25 \\
\hline $\mathrm{d}$ & $\begin{array}{l}\text { Apakah guru } \\
\text { memberikan } \\
\text { memberikan nilai } \\
\text { pada lembar kerja } \\
\text { siswa? }\end{array}$ & 11 & 91,7 & 1 & 8,3 \\
\hline & Jumlah & 142 & 74 & 50 & 26 \\
\hline
\end{tabular}

Dari data rekapitulasi di atas maka dapat diketahui bahwa hasil observasi untuk alternatif jawaban "ya" berjumlah 142 sedangkan untuk alternatif jawaban "tidak" berjumlah 50 , untuk memperoleh persentase dari rekapitulasi hasil observasi Untuk mendapatkan nilai $\mathrm{F}$ dengan cara memberikan bobot pada jawaban hasil observasi, sebagai mana berikut:

Untuk alternatif jawaban "ya" dengan bobot 1 sehingga didapatkan hasil: 142 x $1=142$

Untuk alternatif jawaban "tidak" dengan bobot 0 sehingga didapat nilai: $50 \times 0=0$
Dari hasil kedua tersebut ditambahkan sehingga diperoleh: $\mathrm{F}=142+0=142$

Dan untuk memperoleh nilai $\mathrm{N}$ dengan menggunakan rumus sebagai berikut:

$\mathrm{N}=$ Item $\mathrm{x}$ Skor tertinggi $\mathrm{x}$ Jumlah observasi $\mathrm{x}$ responden

$\mathrm{N}=16 \times 1 \times 6 \times 2$

$\mathrm{N}=192$

Setelah itu untuk mencari rata-rata persentase dengan menggunakan rumus sebagai berikut:

$$
\begin{aligned}
& \mathrm{P}=\frac{\mathrm{F}}{\mathrm{N}} \times 100 \% \\
& \mathrm{P}=\frac{142}{192} \times 100 \% \\
& \mathrm{P}=\mathbf{7 4 \%}
\end{aligned}
$$

Dari hasil perhitungan di atas, maka dapat penulis simpulkan bahwa "Kinerja guru Pendidikan Agama Islam dalam mengimplementasi Rencana Pelaksanaan Pembelajaran (RPP) pada proses pembelajaran Pendidikan Agama Islam di Sekolah Menengah Pertama Muhammadiyah Tembilahan" nilai persentasenya adalah $74 \%$, dan tergolong "Baik" karena terletak pada interval $61 \%-80 \%$.

\section{KESIMPULAN}

Berdasarkan hasil penelitian dapat disimpulkan bahwa Kinerja guru Pendidikan Agama Islam dalam mengimplementasi Rencana Pelaksanaan Pembelajaran (RPP) pada proses pembelajaran Pendidikan Agama Islam di Sekolah Menengah Pertama Muhammadiyah Tembilahan" nilai persentasenya adalah $74 \%$, dan 
tergolong Baik karena terletak pada interval $61 \%-80 \%$.

\section{REFERENSI}

Ahmadi, Guru dan Langkah-langkah Pembelajaran, Jakarta: Atlanta Press, 2009.

Anas Sudijono, Pengantar Statistik Pendidikan. Jakarta: Raja Grafindo Persada, 2001.

Andi Prastowo, Pendidikan religiositas: gagasan, isi, dan pelaksanaannya, Jakarta: Kencana, 2015.

Anwar Prabu Mangkunegara, Manajemen SDM Perusahaan, Bandung: PT. Remaja Rosdakarya, 2000.

Asep Saepul Hamdani, Metode Penelitian Kuantitatif Aplikasi dalam Pendidikan, Yogyakarta: Deepublish, 2014.

Bimo Walgito, Bimbingan dan Konseling, Yogyakarta: Andi Offset, 2010.

Dahar Sulaiman, Evaluasi Hasil Belajar, Bandung: Kalam Mulia, 2010.

Depdiknas, Manajemen Peningkatan Mutu Berbasis Skeola, Jakarta: Dir PMU, 2000.

Etta Mamang Sangadji dan Sopiah, Metodologi Penelitian Pendekatan Praktis dalam Penelitian. Yogyakarta: Andi Offset, 2010.

Ferry Efendi dan Makhfudli, Keperawatan Kesehatan Komunitas, Jakarta: Salemba Medika, 2009.

Kartono, Pengembangan Kurikulum KTSP, Jakarta: Gagas Media, 2009.

Kunandar, Guru Profesional, Impelemtasi Kurikulum Tingkat Satuan Pendidikan KTSP) dan Sukses dalam sertifikasi Guru, Jakarta: Rajawali Pers, 2014.

Ma'as Shobirin, Konsep dan Implementasi Kurikulum 2013 di Skeolah Dasar, Yogyakarta: Deepublish, 2013.

Melayu Hasibuan, Manajemen Sumber Daya Manusia, Yogyakarta: Sinar Grafika Offset, 2002.
Moh. Uzer Usman, Menjadi Guru Profesional, Jakarta: Bandung: Remaja Rosdakarya, 2009.

Rahmat Alyakin Dachi, Proses dan Analisis Kebijakan Kesehatan Suatu Pendekatan Konseptual), Yogyakarta: Deepublish, 2017.

Riduwan, Belajar Mudah Penelitian untuk Guru, Karyawan dan Peneliti Pemula, Bandung: Alpabeta, 2005.

Saudah Racman, Implementasi Kebijakan Perusahaan, Bandung: Econom.Ce, 2007.

Soetopo, Pelaksanaan Kurikulum Berbasis Kompetensi, Bandung: Kalam Mulia, 2006.

Sofan Amri dan Lif Khairu Ahmadi, Kontruksi Pengembangan Pembelajaran, Bandung: Alfabeta, 2010.

Subana, dkk. Statistik Penelitian, Bandung: Pustaka Setia, 2005.

Tim Penyusun Kamus Pusat Bahasa, Kamus Besar Bahasa Indonesia, Edisi Ketiga, Jakarta: Balai Pustaka, 2005.

Werkanis dan Marlius Hamadi, Strategi Mengajar, dalam pelaksanaan Kurikulum Berbasis Kompetensi, Pekanbaru: Sutra Benta Perkasa, 2005. Winarno, Metodologi Penelitian, Malang: Universitas Negeri Malang, 2005.

Wirawan, Evaluasi Kinerja, Jakarta: Erlangga, 2001. 